\title{
ビューシーケンスに基づく 照明変化に頑健な屋内外ナビゲーション
}

\author{
山 城 容一朗* 怡 土 順 一* 竹 村 憲太郎* \\ 松 本 吉 央* 高松淳* 小笠原司*

\section{Indoor and Outdoor Navigation based on View Sequence under Variable Illumination Condition}

\author{
Yoichiro Yamagi*, Junichi Ido*, Kentaro Takemura*, Yoshio Matsumoto*, \\ Jun Takamatsu* and Tsukasa Ogasawara*
}

\begin{abstract}
We propose a view-based indoor/outdoor navigation method as an extension of the view-sequence navigation. The original view-sequence navigation method uses block matching with normalized correlation for localization, which is sensitive to local illumination changes. Therefore it is only applied for indoor environment. In this paper, we adopt accumulated block matching for improving the robustness against locally changing illumination, in which a template is divided into a set of small patches, and each patch is utilized for matching. We also propose localization criteria which help a robot decide its motion. Our experimental results demonstrate the proposed methods can be applied for indoor/outdoor environments.
\end{abstract}

Key Words: View based Navigation, Indoor/Outdoor, View Sequence, Illumination Condition

\section{1. は じめに}

移動ロボットに関する研究の進展に伴い, 警備巡回監視ロボッ ト [1] や館内案内ロボット [2] など, 実際の環境中を自律移動し ながらサービスを提供することにより，我々の生活をサポート するロボットシステムが注目されている。警備・案内というあ る特定の目的に特化したロボットの場合, 制限された活動範囲 を行動できれば十分であるが, 沉用的なロボットを用いてょり よいサービスを実現するためには, 異なる建物間の移動等, 屋 内外を問わずシームレスに移動できるシステムが必要不可欠と なる。

そこで本研究では, 屋内外のシームレスなナビゲーションを 同一アルゴリズムで実現する方法を提案する，同一アルゴリズ ムを用いることにより，屋内外で手法を区別する必要がなく，実 現が簡単となる. 本稿では, 屋内での自律移動手法として提案 されたビューシーケンスナビゲーション [3] を拡張し, 屋外の照 明条件（時間経過による光源の位置，明るさの変化抒よびそれ に伴う陰影）の変化に対する頑健性を向上することで屋内外の シームレスな走行を実現する.

原稿受付 2008 年 12 月 19 日

*奈良先端科学技術大学院大学

*Nara Institute of Science and Technology

ロ 本論文は有用性で評価されました。
以下，本稿は次のような構成となっている，第 2 章では関連 研究を紹介し, 本研究のアプローチについて述べる. 第 3 章で は照明変化に対応したナビゲーション手法を提案する. 第 4 章 では, 提案手法の有効性を示すために, 従来手法との比較実験 結果抢よび屋内外の連続的な走行実験の結果について述べる. 最後に第 5 章で, まとめと今後の課題について述べる.

\section{2. 関 連 研 究}

移動ロボットのナビゲーションは，環境中に特殊なデバイス． 視覚マーカ等（本稿では，これをランドマークと定義する）を 利用するか否かにより，大きく二つに分けることができる，前 者の例として, 竹内ら [4] は QR コードを, Kulyukin ら [5]は RFID 夕グを走行環境に設置することでナビゲーションを実現 している. しかし, インフラ整備の必要性やそれらのランドマー クが利用可能な環境に適用が限定されるという問題がある.

これに対して，すでに設置されているランドマークを利用す る手法として，GPS を用いる手法（例えば文献 [6]）がある，通 常 GPS のみでは位置推定精度が低いため, オドメトリとの融 合 $[7]$ や，さらにレーザーレンジファインダとの融合 $[8]$ により 精度を向上する手法も提案されている。しかし GPS は屋内環 境で利用することができない. 吉田ら [9] は，ナビゲーション に利用可能なランドマークとして点字ブロックを利用する手法 を提案している，点字ブロックが設置されている場所はまばら 
であり，適用可能な環境には制限がある.

後者のランドマークに依存しないナビゲーションとして，松 本ら [3] は教示された走行経路画像を再現することにより移動口 ボットのナビゲーションを行うビューシーケンスナビゲーション を提案している．教示画像と観測画像を正規化相関によるテン プレートマッチングにより比較しているため, 照明変化や障害物 により自己位置推定の精度が悪化してしまうという問題がある。 結果として，その利用は屋内に限定されている。障害物による 悪影響を軽減する方法として, 天井画像を利用する方法 [10] [11] が提案されているが, こちらもその利用は屋内に限られる.

これに対し, 桂ら [12] は, 直接画像比較を行うのではなく, 空・木·建物 · 人工物といった画像特徵を学習 · 比較すること により, 照明変化に頑健なビューシーケンスナビゲーションを 提案している. 利用している画像特徵は屋外を想定したものに 限定されており, 屋内に存在する画像特徽がナビゲーションに 利用可能であるかどうかは示されていない.

本研究は適用の容易性を踏まえた上で, 松本らが提案するラ ンドマークに依存しないビューシーケンスナビゲーション [3] を 拡張し, 照明変化に対する頑健性を付与することにより, 屋内 外のシームレスなナビゲーションの実現を目指す。

\section{3. 照明変化に頑健なビューシーケンスナビゲーション}

ビューシーケンスナビゲーション [3] は目標走行経路の見え （ビュー）の連続（シーケンス）を教示し，その見えを再現する ようにロボットを動かすことで自律走行を行う手法である。自 律移動の際には,

(1) 目標のビューと現在のビューとのずれの決定

(2) ビューシーケンス中で目標となるビューの切り替え

(3) ずれに対するロボットのリアクション

の三つが必要になる。

\section{1 累積ブロックマッチング法}

従来のビューシーケンスナビゲーションでは, 正規化相関に よるテンプレートマッチングを用いているため, 局所的な照明 変化に悪影響を受ける問題があった。 そこで, 照明変化に頑健 にするために累積ブロックマッチング法 (ABM: Accumulated Block Matching) [13] を利用する.テンプレートを小領域に分 割し, それらの相関值の平均が最大となる位置をマッチング位 置とする 。本稿で取り扱う局所的な照明変化の問題は元々の手 法が対象としている遮蔽の問題と類似しており，ABM を用い ることで頑健にすることができる.

照明変化への頑健性を評価するため, 屋外に固定カメラ を設置し，10〜16 時の間に 30 秒間隔で 820 枚の画像取得 を行った. 10 時の画像をテンプレートとして正規化相関と $\mathrm{ABM}$ でマッチングを行った際の変位 $\left(x_{\text {error }}, y_{\text {error }}\right)$ の大き さ $\left(\sqrt{x_{\text {error }}^{2}+y_{\text {error }}^{2}}\right)$ を Fig. 1 に示す. カメラは固定されて いるため, 同一位置にテンプレートがマッチングすることが好 ましい. 図より, ABM が正規化相関よりも安定してマッチン グしていることが確認できる。また, 正規化相関でのマッチン グで誤差が大きくなっている時刻（15 時ごろ）のマッチング結 果はFig. 2 となっており, これまで問題とされてきた照明変化
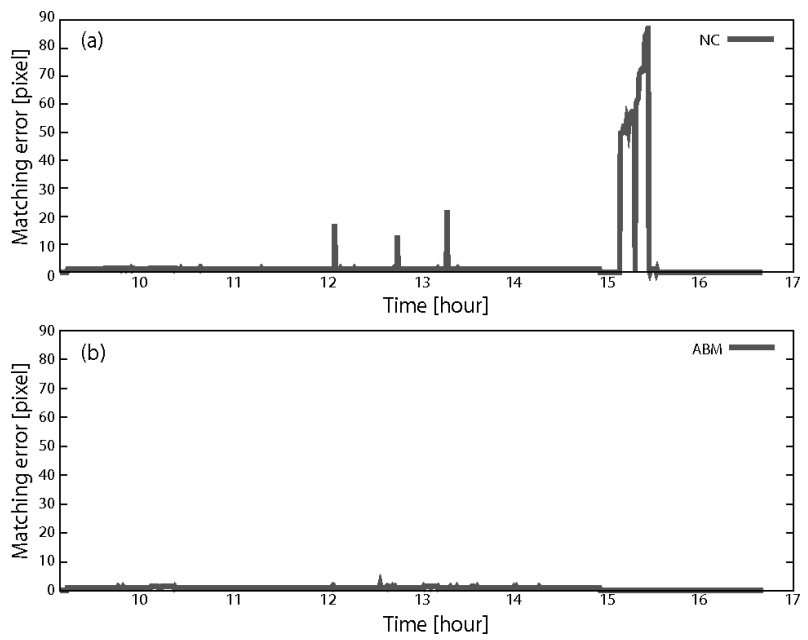

Fig. 1 Matching error using normalized correlation (upper) and using accumulated block matching (lower)

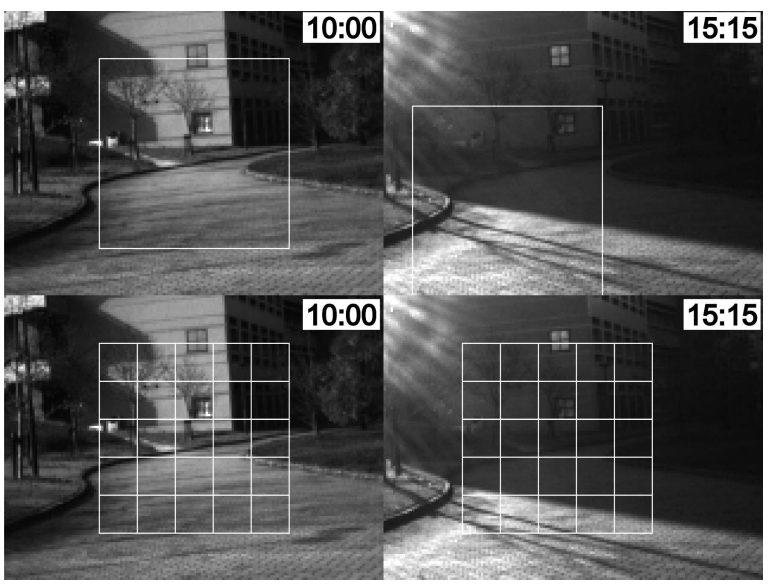

Fig. 2 The result of template matching with a normalized correlation (upper row) and of accumulated block matching (lower row)

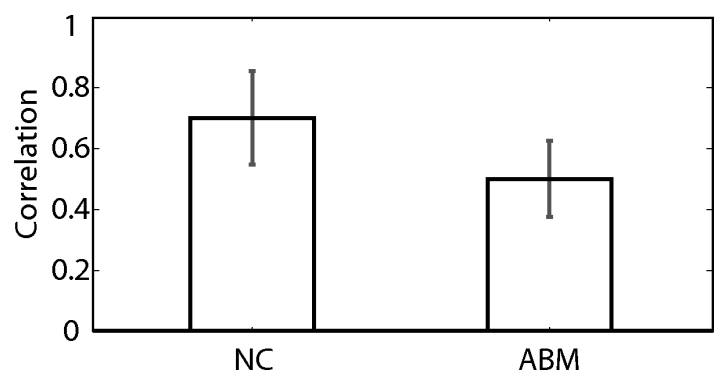

Fig. 3 Normalized correlation in template matching (left) and average of correlations in accumulated block matching (right)

に対応したマッチングを実現できていることが分かる

Fig. 3 は，実験で得られた正規化相関とABM の相関值の平 均を示したものである。これより, 正規化相関よりも $\mathrm{ABM} の$

\footnotetext{
†佐治らはテンプレートの分割数を可変にする手法を提案している [14]. より安定なマッチングを実現するには分割数の可変は重要であるが, 計 算コストが増大するため本稿では分割数は固定とした。
} 


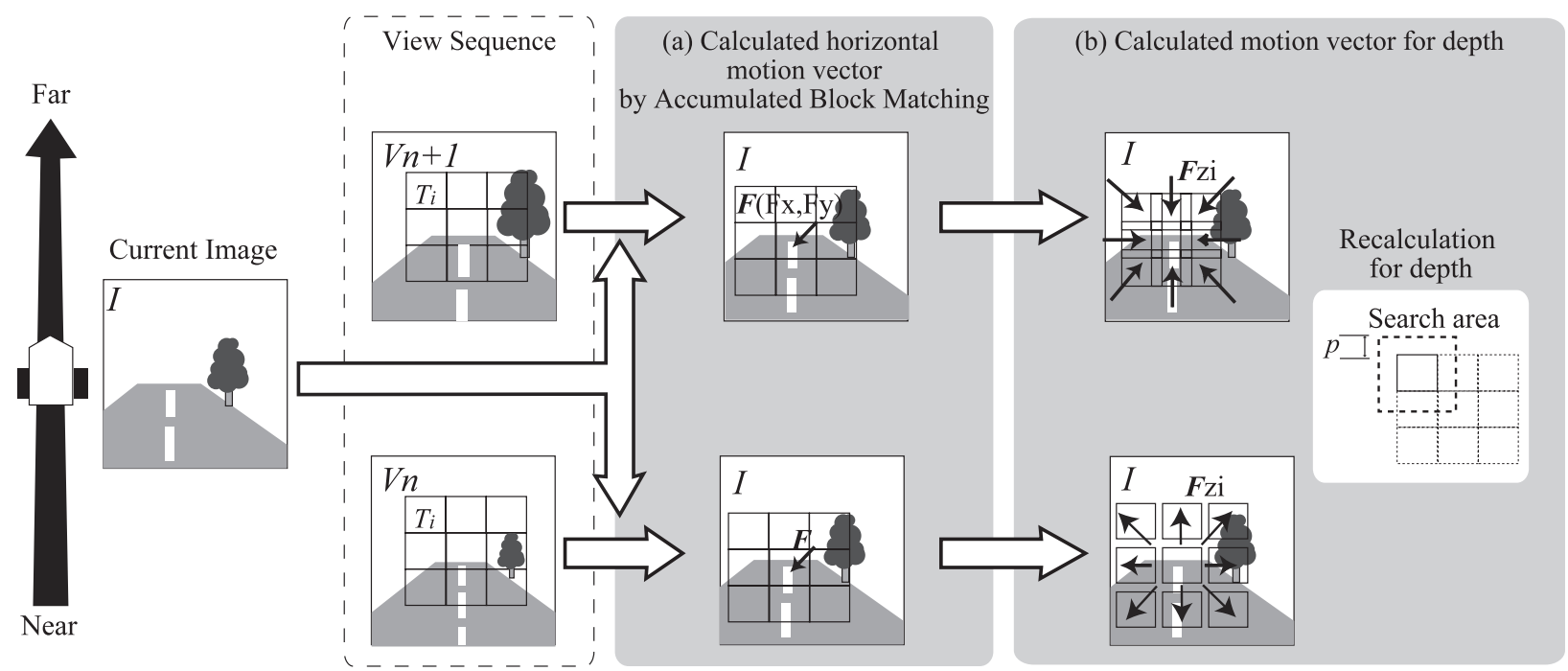

Fig. 4 Calculation of quasi-distance between recorded and current images using our defined motion vectors

方が平均が低くなっていることが分かる。これは，ABM を用 いた場合，小領域に分割し相関值の信頼性が低下したために生 じたと考えられ，このままではビューシーケンスの切り替えが 困難である。よって相関值を利用せずに適切にビューシーケン スを切り替える手法を考える必要がある。

\section{2 画像間移動量}

適切にビューシーケンスを切り替えるため, 2 種類の画像間 移動量を定義する. Fig. 4(a) に示すように, 現在の入力画像 $I$

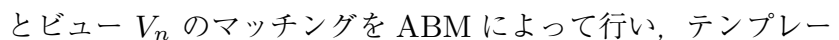
トの移動べクトル $\boldsymbol{F}$ を計算する. この水平成分 $F_{x}$ を画像の水 平移動量と呼ぶ.

次に, Fig.4(b)のようにABM における $m$ 個の小領域 $T_{i}(i=1,2, \ldots, m)$ のマッチング位置をそれぞれの近傍 $p[\mathrm{pixel}]$ の探索範囲で再探索する. その近傍で各小領域の相関值が最大 となる位置を求め, 近傍探索前の位置からの移動べクトル $\boldsymbol{F}_{\boldsymbol{z}}$ を算出し，これを画像の奥行き移動べクトルと定義する。また， 画像の奥行き移動量 $F_{z}$ を相関值 $c_{i}$ が 0 より大きい小領域 $s$ 個の移動べクトルの大きさの平均值として式（1）のように求 める.

$$
F_{z}=\frac{1}{s} \sum_{i \in K}\left|\mathbf{F}_{\mathbf{z} i}\right| \quad\left(K=\left\{i \mid c_{i}>0\right\}\right)
$$

奥行き移動量を安定に推定するため, ノイズの影響を考慮して, 実際の処理では $F_{z}$ にローパスフィル夕（単純移動平均法）を かけた值を用いる。

\section{$3.3 \mathrm{ABM}$ と画像間移動量を用いたビューシーケンス}

屋内外を自律移動するロボットの移動は, Fig. 5 に示すように

(a) 狭い通路でのその場回転

(b) 緩やかな曲線走行を含む直線走行

の 2 種類の移動を考える必要がある.

その場回転の場合, ビューシーケンスの切り替えには水平移 動量 $F_{x}$ を用いる (Fig. $5(\mathrm{a})$ ). 定義より, 水平移動量は教示 の際のビューの向きと現在のビューの向きの差に対応する. 現
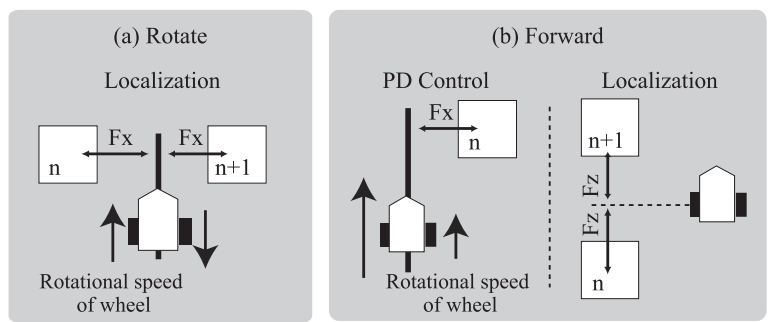

Fig. 5 Robot control and localization

在の目標ビューを $V_{n}$, その次のビューを $V_{n+1}$ とし, 現在の 入力画像 $I$ と 2 枚のビューとの水平移動量をそれぞれ $F_{x(n)}$, $F_{x(n+1)}$ とすると, $F_{x(n)}>F_{x(n+1)}$ となった時点でビューを 切り替え $(n \leftarrow n+1)$ ればよい.

直進走行の場合, ビューシーケンスの切り替えには奥行き移動 量 $F_{z}$ を用いる (Fig. $5(\mathrm{~b})$ ). 具体的には, 現在の入力画像 $I$ と 2 枚のビューとの奥行き移動量 $F_{z(n)}, F_{z(n+1)}$ が $F_{z(n)}>F_{z(n+1)}$ となった時点でビューを切り替える. ロボットが教示ビュー $V_{n}$ が撮影された場所よりも手前に位置した場所から移動を開始す る場合を考える、ロボットが移動するにつれて $F_{z(n)}$ と $F_{z(n+1)}$ は $F_{z(n)}<F_{z(n+1)}$ を満たしながら減少する。 ロボットの位置 が $V_{n}$ の撮影場所に最も近くなったとき， $F_{z(n)}$ は極小值を示す。 その後, $F_{z(n)}$ は増加し $F_{z(n+1)}$ はビュー $V_{(n+1)}$ の撮影場所に 近づくにつれて減少する。 つまり， $F_{z(n)}>F_{z(n+1)}$ となった時 点でビューを切り替えればよい. ちなみに, 教示の際のビュー シーケンスの作成にも, その場回転では水平移動量 $F_{x}$ を, 直 進走行では奥行き移動量 $F_{z}$ を相関值の変わりに用いればよい.

その場回転はビューシーケンスが切り替わるまで回転運動を 続けることで実現できるが, 直進移動の場合は, さらに前進運 動に加え, 教示ビューとの向きのズレに応じて回転運動を行う 必要があり, 水平移動量 $F_{x(n)}$ の大きさをもとに左右のモー夕 の回転速度を決定する. 緩やかな曲線走行の場合は, 直進走行 のアルゴリズムで対応が可能である. 


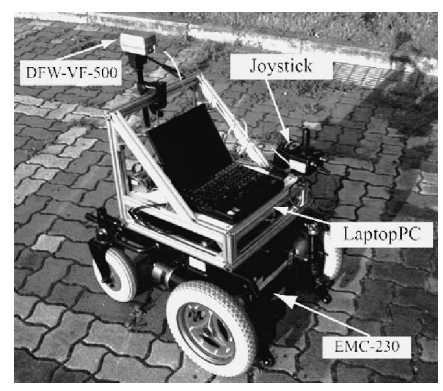

Fig. 6 Mobile Robot (EMC-230)
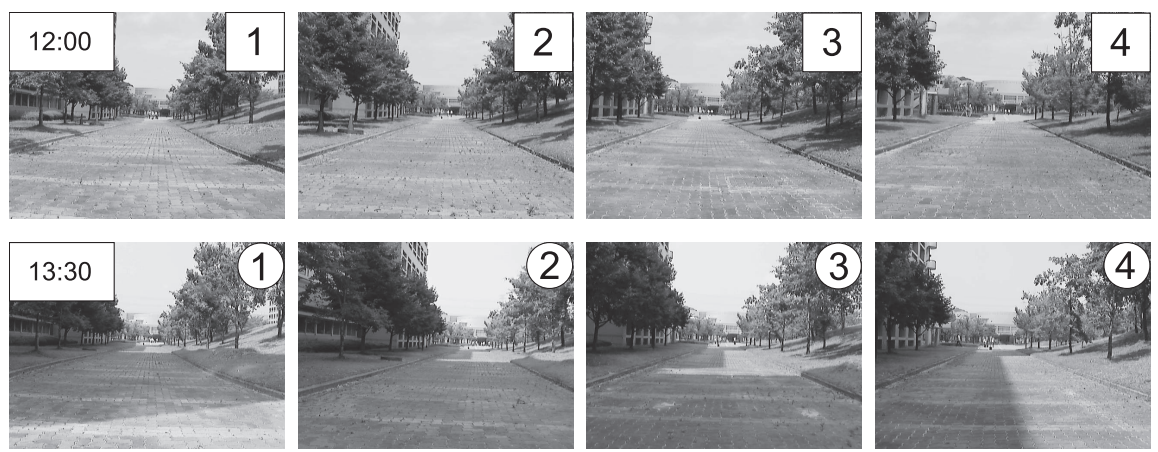

Fig. 7 Recorded image sequences on a path at 12:00 (upper) and at 13:30 (lower)

\section{4. 実}

験

\section{1 ハードウェア構成}

実験に用いる移動ロボット（Fig. 6) として，電動車椅子（今 仙技術研究所：EMC-230）を用いる。ロボットの制御はUSB I/O ボード（テクノウェーブ（株）：USBM3069F）を用いて行 う。また, IEEE1394 カメラ（SONY：DFW-VL-500）を用い ることで, グレースケール画像を取得する. カメラ設定として は，シャッタースピードおよびゲインのオート機能を用いて画 像に適切なコントラストが得られるように調整した。

\section{2 従来手法との比較実験}

提案手法の有用性を示すために, 従来手法との比較実験を 行う. 自律移動を行うためには, 走行中のビューに合わせて, 適切にビューシーケンス中のビューを切り替えていく必要があ る. 実験環境は大学構内の約 $100[\mathrm{~m}]$ の直線経路とし, Fig. 7 はその経路画像の一部である。このように時間が変化すること で，㓌影が大きく異なり画像の見え方が変化する環境で行う. $640 \times 480$ [pixel] から $80 \times 60$ [pixel] に縮小したグレースケー ル画像を入力画像とし, そのうちテンプレート領域は画像中心 の $40 \times 30$ [pixel] とする. 12 時に 2 回と 13 時半に 1 回, 移動 ロボットを手動で走行させ，走行中の画像をすべて記録した. 12 時（1 回目）の画像をビューシーケンスとして, 従来手法と提 案手法の比較を行うが, ビューの枚数がほぼ同数（従来手法： 22 枚, 提案手法 : 24 枚) になるように画像間の移動量の閾値の 調整を行った。具体的には，従来手法では相関值の閾值を 0.9 , 提案手法では 25 個の小領域に分割し, 近傍探索距離 2 [pixel], 画像間移動量の閾值を 1.8 [pixel] と設定した。 また，奥行き移 動量は 20 フレームの時間平均とした.

12 時 (2 回目) と 13 時半の画像に対して走行シミュレーショ ンを行ったところ, 従来手法では Fig. 8, Fig. 9, 提案手法で はFig. 10, Fig. 11 に示す結果が得られた。 それぞれの眓に記 された番号はFig. 7 に記された番号に対応している. Fig. 8 (a) は, 現在画像 $I$ とビュー $V_{n}, V_{n+1}$ との相関值を示しており, $n+1$ 枚目のビューに近づくにつれてビュー $V_{n}$ との相関值は 減少, $V_{n+1}$ の相関值は増加し Fig. 8 (b) に示すようにビューが 逐次切り替わり, 適切に画像列中の位置推定が実現できている. 提案手法では Fig. 10 (a) に示すように, $n+1$ 枚目のビューに 近づくにつれてビュー $V_{n}$ との奥行き移動量は増加, $V_{n+1}$ と の奥行き画像間距離は減少し, Fig. 10 (b) に示すように位置推

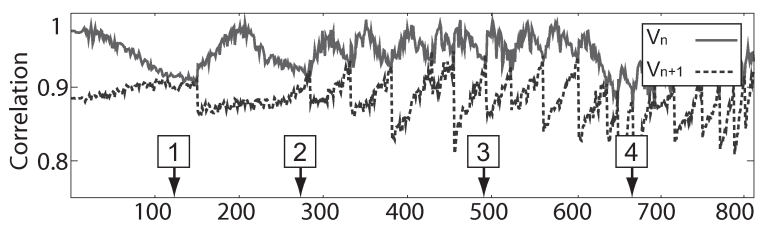

(a)

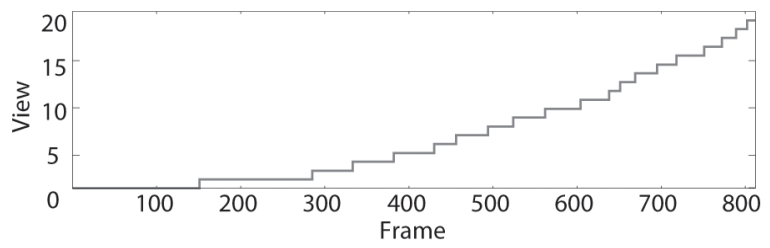

(b)

Fig. 8 Correlation between current image and recorded images (a) and the estimated view ID (b) at 12:00
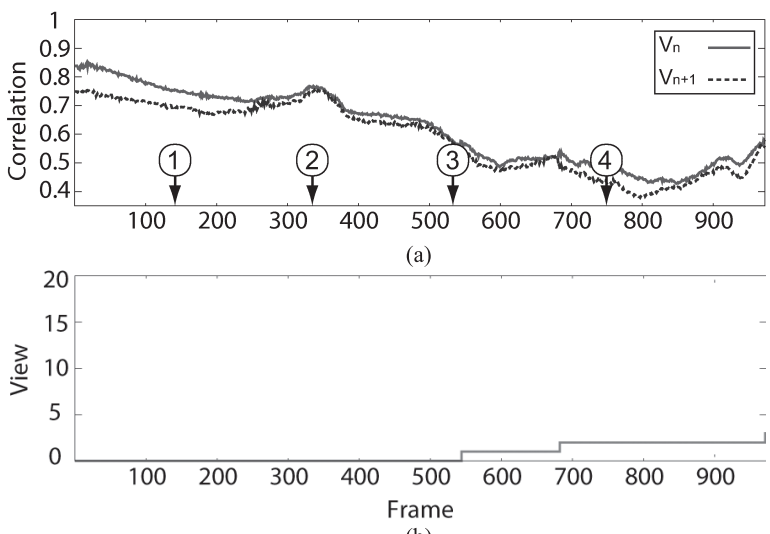

(b)

Fig. 9 Correlation between current image and recorded images (a) and the estimated view ID (b) at 13:30

定が実現できている.

一方, 13 時半の画像に対して従来手法では Fig. 9 のように 12 時の場合と異なりビュー $V_{n}, V_{n+1}$ との相関值がともに減少 してしまい, 適切な位置推定ができていない. これに対して, 提 案手法では Fig. 11 のように, 従来手法ではビューが適切に切 り替わらなかった画像においても画像の移動量が適切に求まり, 正しく位置推定を実現していることが分かる。また，16 時の経 路画像においても従来手法のビューシーケンスでは, ビューが 適切に切り替わらなかったが, 提案手法では適切に動作するこ 


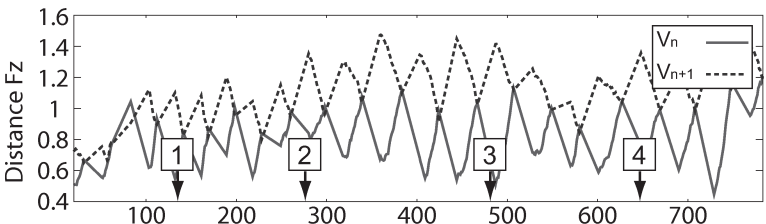

(a)

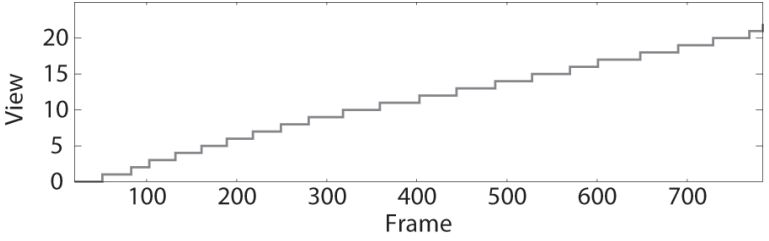

(b)

Fig. 10 Quasi-distance between current image and recorded images (a) and the estimated view ID (b) at 12:00

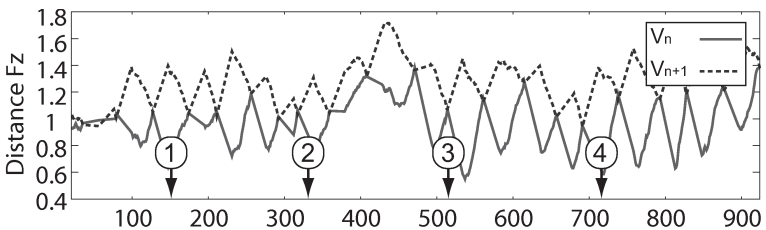

(a)

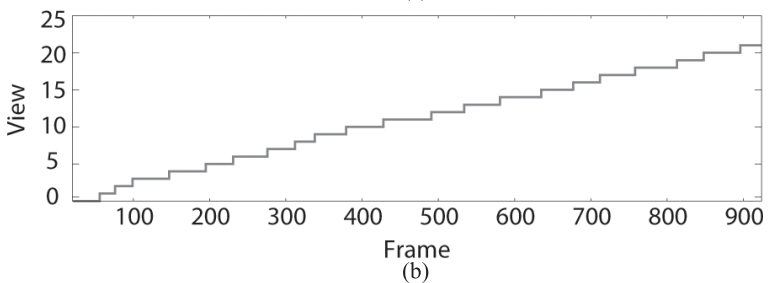

Fig. 11 Quasi-distance between current image and recorded images (a) and the estimated view ID (b) at 13:30

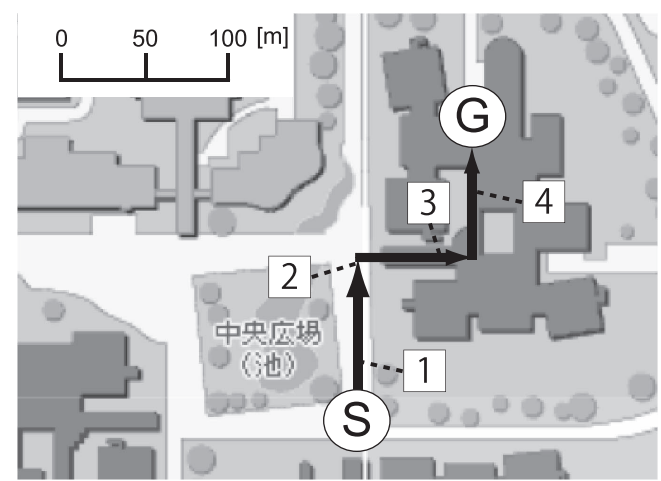

Fig. 12 Indoor/outdoor environments map and robot navigation path

とを確認した。この結果から, 従来手法よりも照明変化に対し て頑健にナビゲーションが可能であることが分かる.

\section{3 屋内外ナビゲーション実験}

奈良先端科学技術大学院大学構内と情報科学研究科棟の 1 階で ナビゲーション実験を行った（Fig. 12）。移動距離は約 $300[\mathrm{~m}]$ で天候は晴れであった，建物へ入る場所に自動扉があるが，実験 時には自動扉は開放したままの状態とした。記録走行では，直 進走行における奥行き移動量の閾值を 1.2 [pixel], その場回転
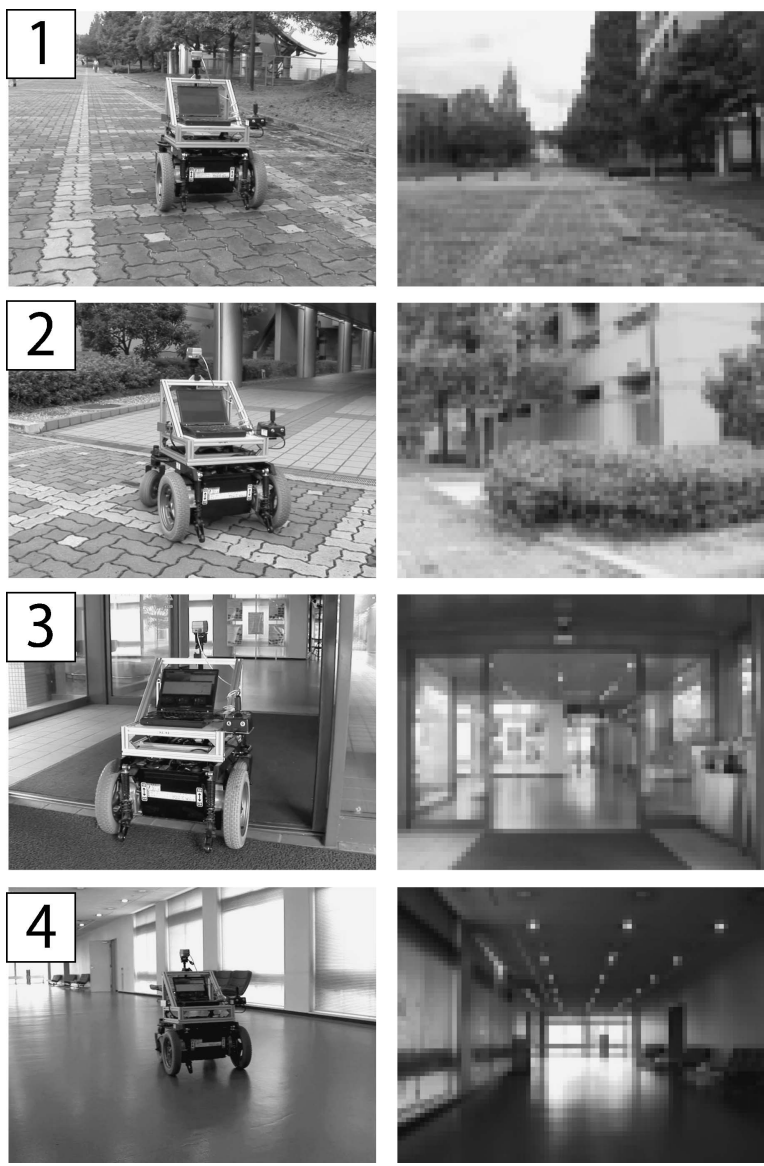

Fig. 13 Snapshots of navigation (Left) and recorded View Sequence image (Right)

における水平移動量の闇值を 10 [pixel] とし, 9 時にビューシー ケンスを作成した，作成されたビューの総数は 95 枚となってい る. Fig. 12 上で表された $\mathrm{S}$ はナビゲーション開始地点, G は終 了地点を表す. Fig. 13 にナビゲーション時のビューの一部とそ のときのロボットの様子を示す．この図上にある番号は Fig. 12 上の位置に対応している。ナビゲーションを 12 時に行ったとこ ろ, ビューが適切に切り替わり, 屋内外環境のナビゲーション を行うことができた。移動ロボットの速度は $1[\mathrm{~km} / \mathrm{h}]$ であり， 経路走行の所要時間は約 20 分であった。この実験によって, 屋 内外を同一アルゴリズムで走行可能であることを示し，またそ の場回転が必要である環境にも適用可能であることを確認した.

\section{5. ま め}

本研究では, 照明変化に適応可能なビューシーケンスナビゲー ションを提案し, 屋内外のシームレスなナビゲーションを実現 した. ビューシーケンスナビゲーションでは, 画像間移動量を推 定することで自律移動を行う。しかしながら従来手法では, 教 示走行から時間が経過すると照明条件の変化が大きい屋外では, 教示画像列との対応関係を頑健に推定することが難しく, 走行 が困難であった。この問題を解決するために，まず，累積ブロッ クマッチング法を用いることで照明変化が生じる環境下におい ても，頑健なマッチングを実現した。また，移動べクトルを用 
いて画像の水平移動量と奥行き移動量を推定し, 直進および回 転制御を行うビューシーケンスナビゲーションを確立した。こ れによって，屋外走行における弱点を大幅に克服し屋内外にわ たるシームレスな自律移動を同一アルゴリズムで実現可能であ ることを示した。

提案手法は照明条件の変化に頑健な手法であると同時に，障 害物が経路上に存在している場合にもナビゲーションが可能と なっている。しかしながら, 照明変化によって生じる陰影と障 害物を区別することは難しく，障害物回避は困難である。より 頑健なナビゲーションを実現するためには, 障害物検出および 回避が重要であるため画像処理技術や他のセンサの利用によっ て対処する必要があり, 今後の課題として取り組む予定である。

\section{参 考 文 献}

[1 ] 下笹: “警備ロボットの現状”, 映像情報メデイア学会誌, vol.57, no.1, pp. 79-82, 2003.

[2] W. Burgard, A. Cermers, D. Hahnel, G. Lakemeyer, D. Schulz, W. Steiner and S. Thrun: "Experiences with an interactive museum tour-guide robot," Artificial Intelligence no.114, pp.3-53, 1999 .

[3] 松本, 稲葉, 井上: “視野画像列を利用した経路表現に基づくナビゲー ション”, 日本ロボット学会誌, vol.15, no.2, pp.236-242, 1997.

[4] 竹内, 太田, 池田, 相山, 新井: “人工ランドマークを用いた移動ロボッ トのナビゲーション”, 日本機械学会論文集 $\mathrm{C}$ 編, vol.66, no.647, pp.2239-2246, 2000.

[5] V. Kulyukin, C. Gharpure, J. Nicholson and S. Pavithran: " "RFID" in robot-assisted indoor navigation for the visually impaired," Proc. of IEEE/RSJ Int. Conf. on Intelligent Robots and Systems, pp.1979-1984, 2004.

[6] E. Abbott and D. Powell: "Land-vehicle navigation using GPS," Proc. of the IEEE, pp.145-162, 1999.

[ 7 ] K. Ohno, T. Tsubouchi, B. Shigematsu, S. Maeyama and S. Yuta: "Outdoor navigation of a mobile robot between buildings based on DGPS and odometry data fusion," Proc. of IEEE Int. Conf. on Robotics and Automation, pp.1978-1984, 2003.

[ 8 ] S.-H. Kim, C.-W. Roh, S.-C. Kang and M.-Y. Park: "Outdoor navigation of a mobile robot using differential GPS and curb detection," Proc. of IEEE Int. Conf. on Robotics and Automation, pp.3414-3419, 2007.

[ 9] 吉田, 大矢, 油田：“点字ブロックを利用した自律移動ロボットの屋外 ナビゲーション”, 日本ロボット学会誌, vol.22, no.4, pp.469-477, 2004.

[10] S. Thrun, M. Beetz, M. Bennewitz, W. Burgard, A. Cremers, F. Dellaert, D. Fox, D. Hähnel, C. Rosenberg, N. Roy, J. Schulte and D. Schulz: "Probabilistic algorithms and the interactive museum tour-guide robot minerva," Int. Journal of Robotics Research, vol.19, no.1, pp.972-999, 2000.

[11] 紙, 松本, 今井, 小笠原: “天井画像列を用いた屋内ナビゲーション”, 第 18 回日本ロボット学会学術講演会予稿集, pp.331-332, 2000.

[12] 桂, 三浦, ヒルド, 白井：“季節や天候の変化にロバストな視覚認識 に基づく移動ロボットの屋外ナビゲーション”, 日本ロボット学会誌, vol.23, no.1, pp.75-83, 2005.

[13] 斉藤: “ブロック照合投票処理を用いた遮へいに強い画像マッチング”, 電 子情報通信学会論文誌, vol.J84-D-II, no.10, pp.2270-2279, 2001.

[14] 佐治，三谷：“可変サイズブロック分割を用いたテンプレートマッチ ング”，電子情報通信学会論文誌，vol.J88-D-II, no.2, pp.450-455, 2005.

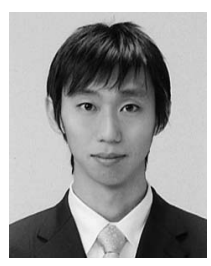

山城容一朗（Yoichiro Yamagi）

2007 年関西大学工学部卒業. 2009 年奈良先端科学 技術大学院大学情報科学研究科博士前期課程修了. 同年, パナソニック株式会社入社. 在学中は移動ロ ボットのナビゲーションの研究に従事.

（日本ロボット学会学生会員）

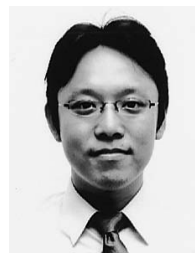

竹村憲太郎 (Kentaro Takemura)

2006 年奈良先端科学技術大学院大学情報科学研究 科博士課程修了。博士 (工学)。同年奈良工業高等 専門学校電気工学科助手, 2007 年同助教. 2008 年 より奈良先端科学技術大学院大学情報科学研究科助 教、移動ロボットおよびヒューマンインターフェー スに関する研究に従事. ACM, IEEE などの会員. （日本ロボット学会正会員）

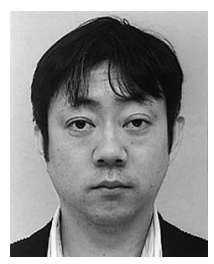

高松 淳 (Jun Takamatsu)

2004 年東京大学大学院情報理工学系研究科コンピ ユー夕科学専攻博士課程修了. 博士 (情報理工学). 東京大学生産技術研究所特任助教, 同特任講師を経 て, 2008 年から奈良先端科学技術大学院大学情報 科学研究科准教授. 知能ロボットの動作獲得, 三次 元形状モデリング・形状解析に関する研究に従事. 電子情報通信学会会員.

（日本ロボット学会正会員）

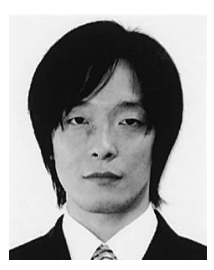

怡土順一（Junichi Ido）

2000 年九州大学工学部機械エネルギー工学科卒業. 2009 年奈良先端科学技術大学院大学上り論文博士 (工学) 取得. 奈良先端科学技術大学院大学研究員 を経て, 2009 年から産業技術総合研究所特別研究 員. ヒューマンロボットインタラクション，ロボッ トビジョンに関する研究に従事.

（日本ロボット学会正会員）

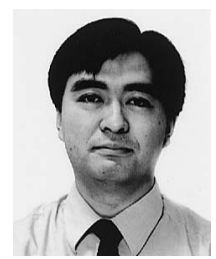

員.

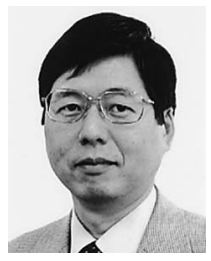

小笠原司 (Tsukasa Ogasawara)

1983 年東京大学大学院工学研究科情報工学専門課 程博士課程修了. 工学博士. 同年通商産業省工業技 術院電子技術総合研究所入所. 1993 1994 年ドイ ツ, カールスルーエ大学客員研究員. 1998 年奈良 先端科学技術大学院大学情報科学研究科教授となり 現在に至る。知能ロボットの研究に従事. 計測自動 制御学会, 情報処理学会などの会員. （日本ロボット学会正会員） 